\title{
The Market for Non-Executive Directors: Does Acquisition Performance Influence Future Board Seats?
}

\author{
Svetlana Mira (1), ${ }^{1}$ Marc Goergen (1D) 1,2 and Noel O'Sullivan (1D) 3 \\ ${ }^{1}$ Cardiff Business School, Cardiff University, Cardiff CF10 3EU, UK, ${ }^{2}$ European Corporate Governance \\ Institute (ECGI), Brussels, Belgium, and ${ }^{3}$ School of Business and Economics, Loughborough University, \\ Loughborough LE11 3TU, UK \\ Corresponding author email: miras@cardiff.ac.uk
}

\begin{abstract}
This paper investigates whether non-executive directors associated with good (bad) board decisions are subsequently rewarded (penalized) in the market for directors. This question is addressed by assessing whether the post-acquisition performance of acquiring companies influences the number of non-executive directorships that non-executives involved in these acquisitions hold subsequent to the acquisition. We find that non-executives on the boards of acquirers that increase (omit or cut) their dividend subsequently hold more (fewer) non-executive directorships in listed companies. Our findings suggest that the nonexecutive labour market is efficient and rewards (penalizes) non-executives for good (bad) acquisitions.
\end{abstract}

\section{Introduction}

In the UK, over the past 25 years the board of directors has been emphasized as one of the most important instruments of corporate governance. Central to this has been an emphasis on

We are grateful to Geoffrey Wood, the Editor, Douglas Cumming, the Associate Editor in charge of the paper, as well as three anonymous referees for their constructive criticism of our paper. We would also like to thank Jay Dahya and Jarrad Harford for commenting on an earlier version of the paper. The paper also benefitted from the input of conference participants at the 13th Workshop on Corporate Governance and Investment, Cardiff University, 12-13 October 2012; the Asian Conference on Corporate Governance and Business Sustainability (ACCGBS), Assumption University, 7-9 October 2013; the 3rd International Conference on Transforming Management System for Innovation, Development, Nepalese Academy Management, 27-29 March 2015; and seminar participants at the Universities of Edinburgh, Kent, Loughborough, Nottingham-Trent, Oxford Brookes, Reading, Sheffield, St Gallen and Surrey. the monitoring potential of non-executive directors, with successive governance codes stressing the need for significant non-executive participation on boards. ${ }^{1}$ Consequently, a majority of board positions in large UK companies are now held by non-executive directors. The expectation is that non-executives are able to actively monitor the behaviour of management, ensuring that corporate decisions are made in the interests of shareholders.

In parallel, researchers have sought to investigate the governance role of boards, in particular seeking to ascertain whether greater non-executive presence on boards is associated with improved shareholder wealth. However, there exists little consistent evidence that greater non-executive participation is associated with enhanced performance. ${ }^{2}$ The apparent absence of a direct link between board composition and firm

\footnotetext{
${ }^{1}$ See Cadbury (1992), Combined Codes (1999, 2003, 2006, 2008 ) and UK Corporate Governance Codes (2010, 2012, 2014, 2016).

${ }^{2}$ Bhagat and Black (2002) and Hermalin and Weisbach (2003) review research examining the relationship
}

(C) 2018 The Authors. British Journal of Management published by John Wiley \& Sons Ltd on behalf of British Academy of Management. Published by John Wiley \& Sons Ltd, 9600 Garsington Road, Oxford OX4 2DQ, UK and 350 Main Street, Malden, MA, 02148, USA.

This is an open access article under the terms of the Creative Commons Attribution-NonCommercial License, which permits use, distribution and reproduction in any medium, provided the original work is properly cited and is not used for commercial purposes. 
performance has encouraged researchers to pursue other avenues to understand the value of board governance. One such initiative has been research seeking to understand the operation of the market for directors. This research has its roots in the work of Fama (1980) and Fama and Jensen (1983), who argued that the labour market for directors serves as an incentive mechanism for directors to pursue shareholder wealth continuously in their management and monitoring activities. A number of US studies provide some support for the notion that the market for directors seeks to differentiate on the basis of directors' prior performance (Brochet and Srinivasan, 2014; Fich and Shivdasani, 2007; Fos and Tsoutsoura, 2014; Kaplan and Reishus, 1990; Yermack, 2004). However, Harford and Schonlau (2013) and Davidoff, Lund and Schonlau (2014) find that director performance does not appear to be an important determinant of future board positions.

This study examines whether the holding of nonexecutive directorships by non-executives subsequent to their company making an acquisition is sensitive to their company's post-acquisition performance. Focusing on the holding of directorships subsequent to acquisition is useful for two reasons. First, acquisitions are one of the most important strategic decisions made by boards and consequently represent a useful environment in which to ascertain the quality of non-executive decision-making and monitoring (Masulis, Wang and Xie, 2007). ${ }^{3}$ Second, existing research highlights significant variation in the performance of acquiring companies, with a large proportion experiencing weak post-acquisition performance (Agrawal and Jaffe, 2000; Harford, HumpheryJenner and Powell, 2012). Therefore, from a shareholder perspective, it is possible to assess the wealth created (or destroyed) by an acquisition. Consequently, our study undertakes a direct test of whether the quality of non-executive monitoring of director decision-making surrounding a specific corporate event, with a likely substantial impact on

between outside directors and firm performance, while Dalton and Dalton (2005) and Adams, Hermalin and Weisbach (2010) are broader reviews of the governance role of boards.

${ }^{3}$ While typically top executives and external advisors play a key role in an acquisition decision, the UK governance environment holds the whole board accountable and recent governance developments focus much of that responsibility on the non-executive board members. the firm and its shareholders, has an impact on the subsequent holding of non-executive directorships by the non-executives involved.

This study focuses on the UK, as we believe it has a number of distinguishing features that make it an ideal laboratory to test the effectiveness of non-executive monitoring and whether this impacts on subsequent holding of non-executive directorships. First, our study coincides with a period of major reform in the structure of UK boards, with a pronounced increase in the role and responsibilities of non-executive directors (Cadbury, 1992; Combined Codes, 1999, 2003, 2006, 2008; UK Corporate Governance Codes, 2010, 2012, 2014, 2016). Of particular relevance to our study is the emergence over this period of a clear distinction between the executive role of management and the monitoring role of nonexecutives and, hence, a greater emphasis on nonexecutive responsibility to ensure that shareholder interests are pursued continuously in corporate decision-making. ${ }^{4}$

Second, in the UK, CEO-chair duality, that is a single individual assuming the roles of both CEO and chair of the board, has been discouraged by successive corporate governance codes, as well as by institutional investors. As a result, we observe duality in only $15 \%$ of our sample, compared with $64 \%$ in the US sample used by Duru, Wang and Zhao (2013), while Chhaochharia and Grindstein (2007) report CEO-chair duality in $75 \%$ of S\&P 500 firms in 2003 . While it might be relatively easy to adjust for duality if a minority of observations are exhibiting it, making such an adjustment for a sample dominated by duality, such as in the US case, seems less straightforward.

Third, unlike the position in the USA, where companies frequently use staggered boards to prevent director change, in the UK there are no restrictions to hiring and firing directors. This is important for studying the market for directors, as

\footnotetext{
${ }^{4}$ As highlighted by Dahya, McConnell and Travlos (2002), in comparison with the USA, historically UK boards were dominated by executive directors. For example, in 1988 only 21 of the FTSE 500 firms had a majority of non-executive directors, compared with 387 of the Fortune 500 firms. Further, the median UK board comprised only $27 \%$ non-executives compared with $81 \%$ for the median US board. The current study reports a mean proportion of non-executives in acquiring firms of $44 \%$ in 1994 , rising to over $68 \%$ by the end of our sample period in 2010 .
} 
it allows companies to make board changes in a more liberal market environment. Even though not all US-listed companies possess staggered boards, a number of studies illustrate the presence of such boards in a very significant proportion of companies. For example, between 2002 and 2008, Duru, Wang and Zhao (2013) report that $61 \%$ of their sample possessed staggered boards (see also Jiraporn, Chintrakarn and Kim, 2012; Rose, 2009). The absence of impediments to hiring and firing UK board members provides us with the opportunity to investigate the market for non-executive directors in a more market-orientated environment. ${ }^{5}$ Therefore, the move towards greater non-executive monitoring, as well as the relative lack of CEOchair duality and the absence of staggered boards, makes the UK a useful environment to test the impact of acquisitions on the subsequent holding of non-executive directorships.

Our study makes three major contributions to existing research. First, the focus on nonexecutive directors and the impact of acquisition performance on their careers distinguishes our study from that of Harford and Schonlau (2013), who focus predominantly on US CEOs. This is especially important in the context of UK companies, since over the past 25 years there has been a significant enhancement of non-executives' monitoring role and, consequently, they are under increased pressure to ensure value-maximizing decisions on behalf of shareholders. This then implies that those non-executives perceived as being good (bad) monitors are likely to have their careers enhanced (penalized) in the non-executive labour market. Our UK study provides an ideal opportunity to capture this. Second, while Harford and Schonlau (2013) follow directors for a two-year period after the acquisition, we do so for five years. This is important, as the financial impact of acquisitions on shareholder wealth is unlikely to fully materialize within such a short window (Tuch and O'Sullivan, 2007). Therefore, by tracking acquirer performance and board positions over a five-year period, we provide more

\footnotetext{
${ }^{5}$ The acquisition environment in the UK is less regulated than in the USA (Armour and Skeel, 2007). Specifically, UK firms are not permitted to use pre-takeover defensive measures, while such takeover impediments are commonplace in the USA. As shown by, for example, Masulis, Wang and Xie (2007), such anti-takeover provisions significantly distort the wealth implications of US takeovers.
}

comprehensive insights into how the non-executive labour market works. Third, we extend the range of performance measures used in prior work by including dividends as a performance measure. We follow Kaplan and Reishus (1990), who use dividend changes to measure performance in a sample of US firms and find that dividend cuts have a negative impact on the subsequent holding of board seats by those executives. As highlighted by Easterbrook (1984), La Porta et al. (2000), Rozeff (1982) and Sharma (2011), amongst others, shareholders value regular dividends not only because they are a mechanism for returning corporate earnings to investors but also because, by paying regular dividends, companies are forced to return to the capital markets if they require funds. This, in turn, allows investors to exercise some control over directors regarding the management of the company and, of particular relevance to this study, the quality of non-executive monitoring of that management. In this respect, any omission or reduction in dividends post-acquisition can be viewed as a negative outcome for shareholders and is expected to lead to the punishment of the non-executives concerned. Indeed, Sharma (2011) finds that non-executive tenure is sensitive to the continuation of dividends being paid and attributes this to recognition by non-executives of the value to shareholders of maintaining dividend payments.

To answer our research question, we identify successful acquisitions in the UK between 1994 and 2010, as well as the individuals holding non-executive positions on the acquirers' boards on completion of the acquisition. We track the number of non-executive directorships held by each of the individual non-executives for up to five years after the acquisition. We then measure the accounting and market-based performance, as well as the dividend changes of the acquiring firms over the same five years, and investigate whether the subsequent holding of non-executive directorships is sensitive to post-acquisition performance. Hence, our research period effectively ends in 2015. We find that the subsequent holding of non-executive directorships by non-executives is sensitive to the post-acquisition performance of acquirers when this is measured by dividend changes. We consistently find that non-executives on the boards of acquirers that omit or cut their dividend hold fewer non-executive directorships in listed companies than their counterparts on the 
boards of acquirers that increased their dividends, up to five years after completion of the acquisition.

Our paper is structured as follows. The next section reviews existing research on the market for directors and develops our hypothesis. The third section describes the sample, variables, and research methodology. Our empirical analysis is presented in the fourth section. The fifth section performs a number of further and robustness tests and our conclusions are presented in section six.

\section{A review of the evidence on the market for directors}

Fama (1980) and Fama and Jensen (1983) argue that the market for directors serves as an incentive mechanism for directors to pursue shareholder wealth in their management and monitoring activities. A key question addressed in existing research is whether there is a reputation effect in the market for directors, whereby those directors perceived as being good (bad) are rewarded (penalized) with additional (fewer) board positions. Some of the earliest insights into the operation of a market for directors have emerged from studies focusing on the link between firm performance and the holding of outside directorships by CEOs. Brickley, Linck and Coles (1999) show that the probability of retired CEOs holding non-executive appointments in other firms is positively related to their performance as CEOs, while Ferris, Jagannathan and Pritchard (2003) find that the prior performance of a CEO's firm has a positive influence on the number of outside directorships the CEO holds. Similarly, looking at executives more broadly, Kaplan and Reishus (1990) provide evidence that executives in firms that reduce dividends hold fewer non-executive positions three years afterwards. This evidence is broadly consistent with a market for directors where past performance determines the demand for executives to serve as non-executives elsewhere.

In terms of non-executives, the existing evidence suggests that the quality of their monitoring influences the likelihood and number of other board seats they hold. Farrell and Whidbee (2000) find that directors who remove underperforming CEOs are rewarded with additional directorships. Yermack (2004) reports a positive link between the performance of companies and the number of outside directorships subsequently held by outside directors. Similarly, Fich and Shivdasani (2007) find that outside directors of firms subject to financial fraud lawsuits are subsequently punished in the labour market by holding fewer board seats. Overall, this evidence is consistent with non-executives being subject to an active market for their services, with additional appointments being influenced by their past performance as non-executives. However, in a study of the impact of the 2008 financial crisis on the subsequent careers of outside directors in financial firms, Davidoff, Lund and Schonlau (2014) find no evidence that the directors' subsequent careers were affected by poor performance.

Researchers have often focused on corporate acquisitions, since this is one area where the interests of management and shareholders are likely to diverge and, consequently, provides a useful laboratory where the quality of non-executive monitoring may be observed (see e.g. Masulis, Wang and Xie, 2007). Consequently, a number of studies have investigated the impact of nonexecutive and CEO behaviour in the context of acquisitions on their subsequent holding of nonexecutive directorships. For example, Harford (2003) reports that non-executives in poorly performing firms that reject takeover bids are subsequently punished by holding fewer board seats, but those facilitating such takeovers are not similarly penalized. Fairchild and Li (2005) find that directors on the boards of above-averageperforming takeover targets hold more board seats subsequent to the takeover. Fos and Tsoutsoura (2014) find that directors on boards of firms subject to a proxy contest are more likely to lose directorships subsequently. Harford and Schonlau (2013) add to this line of enquiry by focusing on the impact of acquisition performance on the subsequent careers of CEOs. However, their findings suggest that the post-acquisition performance of the acquirers, as measured by market-based and accounting performance, does not impact the number of board seats subsequently held by CEOs, but the latter is heavily influenced by a CEO's acquisition experience. These results are inconsistent with the notion that the labour market rewards the quality of prior decision-making.

Our study also uses acquisitions to provide insights into the labour market for directors. However, unlike Harford (2003) who studies (potential) takeover targets, we focus on the performance of non-executives in acquiring firms. Focusing on 
acquirers helps us to study the operation of the market for directors for at least three reasons. First, the acquisition of another firm represents a discrete event, making robust before and after performance comparisons possible. Second, acquisitions are one of the most important strategic decisions made by boards and hence represent a useful context in which to ascertain the quality of director monitoring and decision-making (Harford, Humphery-Jenner and Powell, 2012; Masulis, Wang and Xie, 2007). Third, a vast literature has investigated the post-acquisition performance of acquirers, with mixed findings regarding the gains to shareholders from such transactions (e.g. Agrawal and Jaffe, 2000; Tuch and O'Sullivan, 2007). Hence, acquisition decisions are an ideal context in which to ascertain whether board members involved in these decisions are rewarded or punished for their impact on shareholder wealth. By undertaking a comparison of the number of non-executive directorships held by the non-executives involved in an acquisition decision in the years after the acquisition is completed, and relating this to the subsequent performance of the acquirer over a similar time period, we can ascertain how the quality of acquisition decisions influences non-executives' subsequent careers. Therefore, we propose the following hypothesis:

H1: The number of non-executive directorships held by a non-executive after an acquisition is sensitive to the post-acquisition performance of the acquiring firm.

\section{Sample selection and methodology}

\section{Sample selection}

Our reference point in time is year 0 , which is the year the acquisition was completed. We obtain the list of UK acquisitions completed by non-financial firms between 1 January 1994 and 31 December 2010 from Thomson One Banker. ${ }^{6}$ There are

\footnotetext{
${ }^{6}$ We exclude financial firms from the analysis and request that the target market value four weeks prior to the announcement of the acquisition is at least $\$ 10$ million and the acquirer owns $100 \%$ of the target after the acquisition. Further analysis suggests that 55 offers are withdrawn during our research period if we replace the requirement of owning $100 \%$ of the target after the acquisition with the requirement that the acquirer seeks to purchase at least $50 \%$ of the target. These offers would be of interest in the context of this research only if the decision to
}

240 acquisitions carried out by 203 acquirers during that period. Since we require data on firm performance for the five years after the acquisition, the period of study effectively ends in 2015. Data on individual non-executive directors is collected from various editions of the Corporate Register, which is published quarterly. Given the study's focus on the acquirer's performance subsequent to the acquisition decision, and its impact on the non-executives' careers, we expect that any consequences (or rewards) arising from the subsequent quality of such acquisitions are dealt out to those in post when the acquisition is completed. Therefore, our sample comprises those non-executives on the board of the acquirer when the acquisition is completed. ${ }^{7}$ We then track the number of nonexecutive directorships in listed firms held by each of these individual non-executives for up to five years after completion of the acquisition. ${ }^{8}$

The Corporate Register enables us to trace all the non-executives for 158 acquirers engaged in 187 acquisitions from the initial sample of 203 acquirers and 240 acquisitions. We identify 678 nonexecutives on the boards of these 158 acquirers in the quarter when the acquisition is completed. As only eight acquirers are listed on the alternative investment market (AIM), we exclude these firms. A further four acquirers (equating to eight acquisitions) are dropped because they were involved in

\footnotetext{
withdraw the offer is driven by the bidder and, in particular, by the non-executive directors on the board of the bidder. A search of the newswires and press in the UK, using the ABI/INFORM Global database, shows that only two out of these 55 offers were withdrawn by the bidders on the grounds that the 'deal is no longer in the interests of shareholders'.

${ }^{7}$ Our results are upheld when using the sample of nonexecutives on the board of the acquirer in the year before the completion of the acquisition.

${ }^{8}$ The definition of directorships does not include directorships in not-for-profit entities and private companies for the following reasons. First, it is difficult to find data on not-for-profit entities. Second, private companies do not normally distinguish between non-executive and executive directors. Third, firms listed on the London Stock Exchange have to comply with the various corporate governance codes (or explain their failure to comply), whereas private companies do not have to comply or explain. This would substantially reduce the demand for non-executives by private companies. Finally, many of the private companies may simply be subsidiaries of listed companies. Hence, there is a danger that by expanding the sample to non-executive directorships in private companies, we may introduce a bias in the data which would be a function of the organizational structure of companies.
} 
two acquisitions each in the same year. ${ }^{9}$ Fourteen directors switched from a non-executive position to an executive position sometime after year 0 , and are therefore excluded from the sample. The final sample comprises 646 non-executives sitting on the boards of 156 acquirers involved in 183 successful acquisitions. Given that some directors participate in more than one acquisition, the total number of observations in the final sample is 771 , related to non-executives involved in 183 acquisitions. Performance data are sourced from Datastream.

\section{Methodology and definition of the variables}

We test the validity of our hypothesis that the number of non-executive directorships held by a nonexecutive is sensitive to the post-acquisition performance of the acquiring firm as follows. We focus on year 5, as the typical tenure in the UK for board members is three years and a five-year period includes at least one incidence of reappointment of the non-executive and/or the chance of a new appointment onto another company's board. Focusing on year 5 also makes sense, as the extant literature suggests that taking a longer post-acquisition perspective provides a better assessment of the performance of acquirers. ${ }^{10}$ We proceed by using negative binomial regressions estimating the number of non-executive directorships held by the nonexecutives in year 5 . We formally test whether a Poisson or a negative binomial model better suits our data using a likelihood-ratio test for overdispersion. The test results reported in Tables 5 and 6 later suggest that the dispersion parameter alpha is significantly different from zero at the $1 \%$ level in all the regressions. This suggests that a negative binomial model better suits our data.

All the regressions include the number of nonexecutive directorships held by the non-executive in the year before completion of the acquisition, non-executive characteristics, as well as CEO, acquirer and acquisition characteristics as control

\footnotetext{
${ }^{9} \mathrm{We}$ include repeat acquisitions by the same acquirer as long as these repeat acquisitions occur in different years. Of the remaining 155 acquirers, 18 were involved in two acquisitions and another three acquirers were involved in three acquisitions in different years.

${ }^{10}$ A review of the literature by Tuch and O'Sullivan (2007) suggests that, although there is no standard period of time to assess the success or otherwise of an acquisition, most of the studies in the field measure the performance of the acquirer five years after the acquisition.
}

variables. ${ }^{11}$ Table A.1 in the Appendix contains the definitions of all the variables.

We use two market-based performance measures (i.e. ANNOUNCEMENT EFFECT and FIVE-YEAR CAR), two dividend change measures (i.e. DIVIDEND INCREASES and DIVIDEND CUTS OR OMISSIONS), as well as three different measures of accounting performance (i.e. ROA, ROE and CASH FLOWITOTAL ASSETS). All the accounting performance measures are industry adjusted by subtracting from each annual observation the mean industry performance using the three-digit SIC codes. ${ }^{12}$ Unless otherwise stated, all performance measures are based on years 1 to 5 and are in the form of two dummy variables, indicating good and bad acquisition performance, respectively. The good (bad) acquisition performance dummy is set to one if the average of the acquirer's performance from years 1 to 5 is positive (negative), and zero otherwise. ${ }^{13}$

\section{Empirical analysis}

\section{Descriptive statistics}

Table 1 reports the distribution across time (Panel A) and across industries (Panel B) of the 183 acquisitions. Panel A shows that, similar to extant studies (see e.g. Martynova and Renneboog, 2006), there is a peak in acquisition activity between 1997 and 2000 . Panel B shows that roughly $31 \%$ of the acquirers are from the Other Industries: most of

\footnotetext{
${ }^{11} \mathrm{We}$ control for the number of non-executive directorships held by the non-executives in the year before the completion of the acquisition in order to allow for potential persistency in the data. We do not consider acquisition proposals stalled by the non-executives, as most of these are likely to be dealt with on a purely internal basis. Nevertheless, we partly alleviate this limitation by controlling for CEO characteristics, which are likely to be negatively related to the likelihood of acquisition proposals being stalled by the non-executives.

${ }^{12} \mathrm{As}$ discussed in the robustness section, our results are upheld when using the industry-adjusted dividend payout as an alternative measure of performance.

${ }^{13}$ We use dichotomous measures of performance instead of continuous measures for the following three reasons. First, this allows for a neater test of our hypothesis by clearly distinguishing between value-destroying and value-creating acquisitions. Second, this approach 'softens' the impact of outliers. This is particularly important as three of our performance measures are based on accounting numbers. Finally, this approach is in line with previous research (e.g. Harford and Schonlau, 2013).
} 
Table 1. Annual and industry distribution of the acquisitions

Panel A. Annual distribution of acquisitions, acquirers and non-executives

\begin{tabular}{|c|c|c|c|c|}
\hline & \multicolumn{2}{|c|}{ Acquisitions } & \multirow[b]{2}{*}{ Acquirers } & \multirow[b]{2}{*}{ Non-executives } \\
\hline & $\mathrm{N}$ & $\%$ & & \\
\hline 1994 & 9 & 4.9 & 9 & 24 \\
\hline 1995 & 12 & 6.6 & 11 & 54 \\
\hline 1996 & 8 & 4.4 & 7 & 29 \\
\hline 1997 & 18 & 9.8 & 14 & 54 \\
\hline 1998 & 20 & 10.9 & 20 & 59 \\
\hline 1999 & 36 & 19.7 & 32 & 101 \\
\hline 2000 & 24 & 13.1 & 19 & 86 \\
\hline 2001 & 10 & 5.5 & 9 & 42 \\
\hline 2002 & 6 & 3.3 & 5 & 19 \\
\hline 2003 & 7 & 3.8 & 6 & 31 \\
\hline 2004 & 5 & 2.7 & 4 & 24 \\
\hline 2005 & 9 & 4.9 & 7 & 34 \\
\hline 2006 & 8 & 4.4 & 7 & 43 \\
\hline 2007 & 5 & 2.7 & 4 & 21 \\
\hline 2008 & 2 & 1.1 & 1 & 8 \\
\hline 2009 & 1 & 0.6 & 0 & 5 \\
\hline 2010 & 3 & 1.6 & 1 & 12 \\
\hline Total & 183 & 100.0 & 156 & 646 \\
\hline
\end{tabular}

Panel B. Industry distribution of the acquirers using the Fama and French classification

\begin{tabular}{lrr}
\hline Industry & Acquirers & $\%$ \\
\hline 1. Consumer non-durables & 18 & 11.5 \\
2. Consumer durables & 3 & 1.9 \\
3. Manufacturing & 20 & 12.8 \\
4. Oil, gas and coal extraction and products & 3 & 1.9 \\
5. Business equipment & 12 & 7.7 \\
6. Telephone and television transmission & 4 & 2.6 \\
7. Wholesale, retail and some services & 37 & 23.7 \\
8. Healthcare, medical equipment and drugs & 6 & 3.9 \\
9. Utilities & 4 & 2.6 \\
10. Other & 49 & 31.4 \\
Total & 156 & 100.0 \\
\end{tabular}

Panel A reports the distribution across time, whereas Panel B reports the distribution across industries of the 183 acquisitions and the 646 non-executives. Six out of the 49 acquirers in the 'Other' industries in Panel B belong to operators of non-residential buildings (real estate) (code 651), another six to business services (code 874) and four to residential construction (code 152). The rest of the acquirers in the 'Other' industries belong to 25 industries with three or less acquirers each. The numbers reported in the last two columns of Panel A and Panel B are based on the first acquisition completed by the acquirers and non-executives, respectively.

these firms are operators of non-residential buildings, real-estate investment trusts (REITs) and water transportation services. The second most represented industry is the wholesale and retail industry, with just under $24 \%$ of the acquisitions.

Table 2 provides descriptive statistics for the acquirers and acquisitions in Panel A, their nonexecutives in Panel B and their CEOs in Panel C for year 0 , whereas Panel D compares the proportion of acquirers with good and bad acquisition performance from years 1 to 5 . Some of the acquirers are very large (Panel $A$ ); the average market value of the acquirers is $£ 2.344$ billion, while the median value is only $£ 0.453$ billion. The average percentage of equity held by institutional investors is roughly $24 \%$, and about half of the board is comprised of non-executive directors. The industry-adjusted DEBT-TO-EQUITY RATIO is high, with an average of roughly $110 \%$, but a median of only $10.7 \%$. The mean (median) RELATIVE SIZE of the acquisition is $35.4 \%(22.1 \%)$. The proportion of acquisitions by cash and equity is $14 \%$ and $18 \%$, respectively, with about $16 \%$ of the acquisitions being followed by divestment. As for the 
Table 2. Summary statistics for the 156 acquirers and 646 non-executives

\begin{tabular}{|c|c|c|c|c|c|c|c|}
\hline & Mean & S.D. & Min & $\mathrm{P} 25$ & $\mathrm{P} 50$ & P75 & $\operatorname{Max}$ \\
\hline \multicolumn{8}{|l|}{ Panel A. Acquirer and acquisition characteristics } \\
\hline Market value (£m) & 2,344 & 7,656 & 18 & 167 & 453 & 1,547 & 77,043 \\
\hline Total assets $(£ \mathrm{~m})$ & 3,227 & 13,700 & 39 & 208 & 568 & 2,007 & 162,000 \\
\hline Institutional ownership & 0.237 & 0.170 & 0.000 & 0.108 & 0.217 & 0.335 & 0.781 \\
\hline Proportion of non-executives on the board & 0.493 & 0.129 & 0.167 & 0.400 & 0.500 & 0.571 & 0.800 \\
\hline Debt-to-equity ratio & 1.102 & 7.220 & -3.546 & -0.179 & 0.107 & 0.366 & 62.547 \\
\hline Relative size & 0.354 & 0.386 & 0.001 & 0.086 & 0.221 & 0.542 & 2.514 \\
\hline Premium & 33.419 & 28.331 & -98.030 & 15.050 & 33.110 & 46.070 & 135.630 \\
\hline Cash dummy & 0.142 & 0.350 & 0.000 & 0.000 & 0.000 & 0.000 & 1.000 \\
\hline Stock dummy & 0.180 & 0.386 & 0.000 & 0.000 & 0.000 & 0.000 & 1.000 \\
\hline Divestment dummy & 0.158 & 0.366 & 0.000 & 0.000 & 0.000 & 0.000 & 1.000 \\
\hline \multicolumn{8}{|l|}{ Panel B. Non-executive characteristics } \\
\hline Non-executive tenure (years) & 4.897 & 4.941 & 0.008 & 1.581 & 3.441 & 6.408 & 28.394 \\
\hline Non-executive age (years) & 59.115 & 7.356 & 35.584 & 54.085 & 59.896 & 64.430 & 80.430 \\
\hline Non-executive age dummy & 0.492 & 0.500 & 0.000 & 0.000 & 0.000 & 1.000 & 1.000 \\
\hline Non-executive ownership & 0.002 & 0.010 & 0.000 & 0.000 & 0.000 & 0.000 & 0.125 \\
\hline Chair dummy & 0.121 & 0.326 & 0.000 & 0.000 & 0.000 & 0.000 & 1.000 \\
\hline \multicolumn{8}{|l|}{ Panel C. CEO characteristics } \\
\hline CEO ownership & 0.015 & 0.045 & 0.000 & 0.001 & 0.001 & 0.008 & 0.355 \\
\hline Duality & 0.131 & 0.339 & 0.000 & 0.000 & 0.000 & 0.000 & 1.000 \\
\hline \multicolumn{8}{|l|}{ Panel D. Acquirers' performance } \\
\hline & Good acq. perf. (= 1) & \multicolumn{3}{|c|}{ Bad acq. perf. $(=0)$} & \multicolumn{3}{|c|}{ Differences in proportions (z-test) } \\
\hline Announcement effect & 0.397 & \multicolumn{3}{|c|}{0.577} & \multicolumn{3}{|c|}{$-3.171 * * *$} \\
\hline Five-year CAR & 0.423 & \multicolumn{3}{|c|}{0.474} & \multicolumn{3}{|c|}{-0.911} \\
\hline Dividend increases & 0.417 & \multicolumn{3}{|c|}{0.583} & \multicolumn{3}{|c|}{$-2.944 * * *$} \\
\hline Dividend cuts or omissions & 0.493 & \multicolumn{3}{|c|}{0.506} & \multicolumn{3}{|c|}{0.227} \\
\hline ROA & \multirow{2}{*}{0.718} & \multicolumn{3}{|c|}{0.218} & \multicolumn{3}{|c|}{$8.850 * * *$} \\
\hline ROE & & \multicolumn{3}{|c|}{0.410} & \multicolumn{3}{|c|}{$2.042 * *$} \\
\hline Cash flow/total assets & 0.635 & \multicolumn{3}{|c|}{0.237} & \multicolumn{3}{|c|}{$7.079 * * *$} \\
\hline
\end{tabular}

This table provides summary statistics for acquirers, acquisitions, non-executive and CEO characteristics for the year of the completion of the acquisition (year 0), except for Panel D, which compares the proportion of acquirers with good and bad performance from year 1 to year 5. ROA (return on assets), ROE (return on equity) and CASH FLOWITOTAL ASSETS dummies are based on the average of the acquirer's performance over years 1 to 5 . If the average is positive, the good acquisition performance dummy is set to one, and zero otherwise. The bad acquisition performance dummy is set to one if the average is negative, and zero otherwise. The DIVIDEND INCREASES dummy equals one if there has been at least one increase in dividends with no cuts or omissions between year 1 and year 5, and zero otherwise. The DIVIDEND CUTS OR OMISSIONS dummy is set to one if there is at least one dividend cut or omission between year 1 and year 5, and zero otherwise. The good acquisition performance dummies for the ANNOUNCEMENT EFFECT and FIVE-YEAR CAR are set to one if the cumulative abnormal returns for day -1 to +1 and month 1 to 60 , respectively, are positive, and zero otherwise. The bad acquisition performance dummies for the ANNOUNCEMENT EFFECT and FIVE-YEAR $C A R$ are the equivalent dummies for negative cumulative abnormal returns. The equivalent two percentages do not add to $100 \%$ as for a small number of acquirers the return data required to calculate the respective abnormal returns is not available. All the accounting performance measures and DEBT-TO-EQUITY RATIO are industry-adjusted. Differences in proportions in Panel D are assessed using a proportion test. The remaining variables are defined in Table A.1.

$*, * *, * * *$ Statistical significance at the $10 \%, 5 \%$ and $1 \%$ level, respectively.

non-executives (Panel B), their TENURE with the firm is on average around 5 years, while the median is 3.4 years; their average $A G E$ is about 59 years, and $49 \%$ of the non-executives are 60 years or older. Non-executives hold little or no equity in their firms, although $79.2 \%$ of non-executives in the sample (not tabulated) hold some equity. $12 \%$ of non-executives also chair their boards. As for CEO characteristics (Panel C), average CEO OWNERSHIP is $1.5 \%$ with a median of only $0.1 \%$, 
Table 3. Number of directorships, age and year of departure from the market for the 646 non-executives

(Year 5-

Year 0 Year 1 Year 2 Year 3 Year 4 Year 5 Year 0)

\begin{tabular}{|c|c|c|c|c|c|c|c|}
\hline Non-executive directorships held by all non-executives in the sample & 1.99 & 1.79 & 1.61 & 1.42 & 1.25 & 1.05 & $-16.91 * * *$ \\
\hline \multicolumn{8}{|l|}{ Only non-executives still in the sample in year 5} \\
\hline under 60 in year 0 & 2.12 & 2.11 & 2.10 & 2.03 & 2.04 & 1.96 & $-1.76^{*}$ \\
\hline 60 and over in year 0 & 2.69 & 2.44 & 2.23 & 2.12 & 1.96 & 1.69 & $-7.87 * * *$ \\
\hline $\begin{array}{l}\text { Non-executive directorships in companies listed on the Official List } \\
\text { held by all non-executives in the sample }\end{array}$ & 1.93 & 1.72 & 1.54 & 1.33 & 1.15 & 0.96 & $-18.98 * * *$ \\
\hline \multicolumn{8}{|l|}{ Only non-executives still in the sample in year 5} \\
\hline under 60 in year 0 & 2.07 & 2.02 & 1.98 & 1.92 & 1.88 & 1.80 & $-3.32 * * *$ \\
\hline 60 and over in year 0 & 2.60 & 2.37 & 2.15 & 1.98 & 1.82 & 1.53 & $-8.61 * * *$ \\
\hline $\begin{array}{l}\text { Non-executive directorships in AIM listed companies held by all } \\
\text { non-executives in the sample }\end{array}$ & 0.06 & 0.07 & 0.08 & 0.09 & 0.09 & 0.09 & $1.73^{*}$ \\
\hline \multicolumn{8}{|l|}{ Only non-executives still in the sample in year 5} \\
\hline under 60 in year 0 & 0.05 & 0.09 & 0.12 & 0.11 & 0.16 & 0.16 & $2.86^{* * *}$ \\
\hline 60 and over in year 0 & 0.09 & 0.06 & 0.08 & 0.14 & 0.14 & 0.16 & $1.84^{*}$ \\
\hline \multicolumn{8}{|c|}{ Panel B. Number and percentage of non-executives who exit the market for directors according to age } \\
\hline Left the sample & - & 65 & 109 & 170 & 221 & 280 & \\
\hline$\%$ & - & 10.1 & 16.9 & 26.3 & 34.2 & 43.3 & \\
\hline of which 60 and over & - & 42 & 71 & 109 & 151 & 179 & \\
\hline$\%$ & - & 64.6 & 65.1 & 64.1 & 68.3 & 63.9 & \\
\hline In the sample & 646 & 581 & 537 & 476 & 425 & 366 & \\
\hline$\%$ & 100.0 & 89.9 & 83.1 & 73.7 & 65.8 & 56.7 & \\
\hline of which 60 and over & 318 & 276 & 247 & 209 & 167 & 139 & \\
\hline$\%$ & 49.2 & 47.5 & 46.0 & 43.9 & 39.3 & 37.9 & \\
\hline
\end{tabular}

Panel A reports the average number of non-executive directorships for all the 646 non-executives for the year in which the acquisition was completed and the subsequent five years. The panel also reports the equivalent number of non-executive directorships in companies listed on the Official List and those listed on AIM. These numbers are also reported separately by age for those non-executives that remain in the sample until year 5. A non-executive is considered to remain in the sample until year 5 if he/she has at least one nonexecutive directorship on any firm's board. A distinction is made between those non-executives that are 60 years or older in year 0 and those that are younger. The last column of Panel A reports the t-tests for the difference in means between year 5 and year 0 . Panel B reports the number and percentage of non-executives that leave the labour market for directors during the five years after the acquisition. These numbers are cumulative. A non-executive is assumed to have left the market for directors if his/her non-executive directorships fall to zero by year 5 .

$*, * *, * *$ Statistical significance at the $10 \%, 5 \%$ and $1 \%$ level, respectively.

while approximately $13 \%$ of CEOs also chair their boards.

In terms of performance (Panel D), 57.7\% of the acquirers experience a bad (i.e. negative) shortterm market reaction (ANNOUNCEMENT EFFECT), whereas only $39.7 \%$ of the acquirers have a good (i.e. positive) short-term market reaction, and this difference is significant at the $1 \%$ level. The proportion of acquirers with good acquisition performance from years 1 to 5 is significantly greater across all three accounting performance measures than the equivalent proportion of acquirers with bad acquisition performance, and the difference is significant at the $5 \%$ level or better. In contrast, the proportion of acquirers that cut or omit their dividend in at least one of the five years following the year of the acquisition is approximately half, suggesting an equal distribution between good and bad performers.

Panel A of Table 3 reports the evolution over years 0 to 5 of the number of non-executive directorships held by the 646 non-executives (i.e. those that left the sample before year 5 and those that did not). A non-executive is deemed to remain in the sample until year 5 if he/she has at least one non-executive directorship in any listed firm. The panel also reports the number of non-executives that were younger than 60 years in year 0 , as well as those that were older. The average number of non-executive directorships held by the 646 non-executives is two in year 0 . It drops to one in year 5. While older non-executives tend to have on 
average one additional non-executive directorship in year 0 , amounting to a total of roughly three directorships, this number drops to less than two directorships in year 5. This drop in directorships is significant at the $1 \%$ level. In contrast, younger non-executives experience little change over time in this number.

Most non-executive directorships in year 0 (roughly 97\%, not tabulated) are in firms that are on the Official List. The trends in the number of non-executive directorships in such firms are similar to those for the full sample. Further, for the approximately 5\% (not tabulated) of the non-executives holding at least one non-executive directorship in firms listed on the AIM in year 0 , the number of non-executive directorships on the board of these firms increases rather than decreases from years 0 to 5 . This increase is statistically significant at the $1 \%$ level for younger non-executives. This likely reflects the substantial growth in the AIM during that period (Espenlaub, Khurshed and Mohamed, 2012).

Panel B of Table 3 reports, for each of the years 0 to 5 , the number of non-executives who no longer hold any non-executive directorships. ${ }^{14}$ The numbers are cumulative. There are 280 (i.e. about $43 \%$ of the non-executives) no longer in the labour market in year 5. Exits are particularly frequent in years 3-5. While the vast majority of nonexecutives who exit the labour market are older than 60 years in year 0 , the percentage of younger non-executives who exit the labour market is nevertheless non-negligible, hovering at around a third. This suggests that there is a driver other than age and retirement behind this decline.

\section{Univariate analysis}

Table 4 shows no evidence that non-executives with bad acquisition performance hold fewer nonexecutive directorships in year 5 . We find that the number of non-executive directorships held by the non-executives decreases from years 0 to 5 , regardless of the performance. As highlighted in the previous subsection, age plays an important role but it is not the only driver explaining this decline.

\footnotetext{
${ }^{14} \mathrm{~A}$ search in LexisNexis shows that nine of the 646 nonexecutives died within five years following the year of the acquisition. Our results are upheld after excluding these nine cases.
}

\section{Regression analysis}

Table 5 reports the negative binomial regressions, which estimate the number of directorships held by the non-executive in year $5 .{ }^{15}$ The independent variables are the number of non-executive directorships held in the year before the acquisition is completed (i.e. year -1 ), performance dummies, non-executive, CEO, acquirer and acquisition characteristics.

Regressions (1) to (4) show that the good and bad acquisition performance dummies based on the ANNOUNCEMENT EFFECT and FIVE$Y E A R C A R$ are insignificant. ${ }^{16}$ This suggests that the short- and long-term market reaction to the acquisition does not affect the number of nonexecutive directorships held by the non-executives in year 5. Regressions (5) and (6) measure performance by DIVIDEND INCREASES and DIVIDEND CUTS OR OMISSIONS. The coefficient on DIVIDEND INCREASES is positive and significant at the $5 \%$ level, whereas the coefficient on DIVIDEND CUTS OR OMISSIONS is negative and significant at the $5 \%$ level. In contrast, all the remaining performance measures used in regressions (7) to (12) are insignificant. Hence, there is no evidence that non-executives of acquirers with bad market or accounting-based performance hold fewer non-executive directorships in year 5 . However, we find strong support for our hypothesis when performance is measured by dividend changes. Based on the marginal effects, on average the number of non-executive directorships held by the non-executives in year 5 increases (decreases) by $0.219(0.216)$ units if DIVIDEND INCREASES (DIVIDEND CUTS OR OMISSIONS) switches from 0 to 1 , with all the other variables in the model being held constant. This suggests that the number of subsequent directorships held by non-executives five years post-acquisition is neither explained by the market nor the accounting performance measures, but is sensitive to dividend changes.

In terms of the control variables, the coefficient on NON-EXECUTIVE DIRECTORSHIPS measured in the year before the acquisition is positive and significant at the $1 \%$ level in all the regressions. This suggests persistency in the number

\footnotetext{
${ }^{15}$ The $t$-values for the coefficients are heteroscedasticityconsistent and the standard errors are clustered by nonexecutives.

${ }^{16}$ Similar results are obtained when using buy-and-hold abnormal returns.
} 
Table 4. Directorships held by the non-executives and performance dummies over the five years after the acquisition

\begin{tabular}{|c|c|c|c|c|}
\hline & \multirow{2}{*}{$\begin{array}{l}\text { Number of } \\
\text { observations }\end{array}$} & \multicolumn{2}{|c|}{ Mean non-executive directorships in } & \multirow{2}{*}{$\begin{array}{l}\text { t-values/ } \\
\text { z-values }\end{array}$} \\
\hline & & Year 0 & Year 5 & \\
\hline \multicolumn{5}{|l|}{ Announcement effect } \\
\hline Bad acq. perf. & 371 & 2.119 & 1.073 & $-13.37 * * * /-12.61 * * *$ \\
\hline Good acq. perf. & 260 & 1.785 & 1.031 & $-9.90 * * * /-9.47 * * *$ \\
\hline t-values/z-values & & $2.94 * * * / 2.76 * * *$ & $0.39 / 0.20$ & \\
\hline \multicolumn{5}{|l|}{ Five-year CAR } \\
\hline Bad acq. perf. & 299 & 2.067 & 1.077 & $-10.89 * * * /-11.07 * * *$ \\
\hline Good acq. perf. & 287 & 1.899 & 1.014 & $-11.91 * * * /-10.46 * * *$ \\
\hline t-values/z-values & & $1.45 / 0.80$ & $0.57 / 0.54$ & \\
\hline \multicolumn{5}{|l|}{ Dividend changes } \\
\hline Cuts or omissions & 321 & 2.048 & 0.963 & $-13.46^{* * *} /-11.93 * * *$ \\
\hline Increased dividends & 283 & 1.912 & 1.134 & $-9.46 * * * /-9.89 * * *$ \\
\hline $\mathrm{t}$-values/z-values & & $1.17 / 1.25$ & $-1.57 /-1.25$ & \\
\hline \multicolumn{5}{|l|}{ ROA } \\
\hline Bad acq. perf. & 142 & 1.951 & 1.099 & $-6.89 * * * /-6.42 * * *$ \\
\hline Good acq. perf. & 469 & 1.989 & 1.013 & $-15.70 * * * /-14.61 * * *$ \\
\hline t-values/z-values & & $-0.29 /-0.02$ & $0.68 / 0.50$ & \\
\hline \multicolumn{5}{|l|}{ ROE } \\
\hline Bad acq. perf. & 247 & 2.012 & 1.040 & $-11.46^{* * *} /-10.13^{* * *}$ \\
\hline Good acq. perf. & 364 & 1.959 & 1.027 & $-12.62^{* * *} /-12.21 * * *$ \\
\hline t-values/z-values & & $0.46 / 0.56$ & $0.12 / 0.21$ & \\
\hline \multicolumn{5}{|l|}{ Cash flow/total assets } \\
\hline Bad acq. perf. & 156 & 2.006 & 1.064 & $-6.92 * * * /-7.54 * * *$ \\
\hline Good acq. perf. & 405 & 1.970 & 1.007 & $-15.46^{* * *} /-13.26^{* * *}$ \\
\hline t-values/z-values & & $0.27 / 0.18$ & $0.45 / 0.50$ & \\
\hline
\end{tabular}

This table compares the change in directorships over the five years after the acquisition (year 5-year 0) for the 646 non-executives. The table reports the results for six performance measures (i.e. ANNOUNCEMENT EFFECT, FIVE-YEAR CAR, DIVIDEND CHANGES, ROA, ROE and CASH FLOWITOTAL ASSETS). ROA, ROE and CASH FLOWITOTAL ASSETS dummies are based on the average of the acquirer's performance between year 1 and year 5 . If the average performance is positive, the good acquisition performance dummy is set to one, and zero otherwise. The bad acquisition performance dummy is set to one if the average performance is negative, and zero otherwise. The INCREASED DIVIDENDS dummy equals one if there has been at least one increase in dividends with no cuts or omissions between year 1 and year 5. The CUTS OR OMISSIONS dummy equals one if there is at least one dividend cut or omission between year 1 and year 5, and zero otherwise. The good acquisition performance dummies for the ANNOUNCEMENT EFFECT and FIVE-YEAR CAR are set to one if the cumulative abnormal returns for day -1 to +1 and month 1 to 60 , respectively, are positive, and zero otherwise. The negative dummies for the ANNOUNCEMENT EFFECT and FIVE-YEAR CAR are the equivalent dummies for negative CARs. All the accounting performance measures are industry-adjusted. Differences in means are assessed using a t-test, whereas differences in medians are tested using a z-test (Wilcoxon sign-rank test). The Wilcoxon rank-sum test is used to test the equality of medians for the unmatched data when good and bad acquisition performances are compared.

$*, * *, * * *$ Statistical significance at the $10 \%, 5 \%$ and $1 \%$ level, respectively.

of directorships held by the non-executives. All four non-executive characteristics (i.e. TENURE, AGE DUMMY, CHAIR DUMMY and NONEXECUTIVE OWNERSHIP) are also significant in all regressions at the $10 \%$ level or better. ${ }^{17}$ The

\footnotetext{
${ }^{17}$ Untabulated regressions show that non-executive acquisition experience, measured as the number of acquisitions a non-executive has participated in since the beginning of our sample period (i.e. 1994), up to and including year 0, is insignificant in all the regressions and our main regression results are upheld. Focusing our analysis on those non-executive directors involved in only one acquisition does not alter our findings.
}

results suggest that non-executives with longer tenure, those aged 60 and above, and those with greater ownership in the acquirer hold fewer directorships five years after the acquisition. However, non-executives who also chair the board hold more directorships in year 5. Finally, none of the $\mathrm{CEO}$, acquirer or acquisition characteristics are consistently significant across the regressions.

To summarize, there is strong evidence that non-executives with bad (good) acquisition performance are punished (rewarded) by the labour market via fewer (more) board seats in year 5 , but only when acquisition performance is measured 


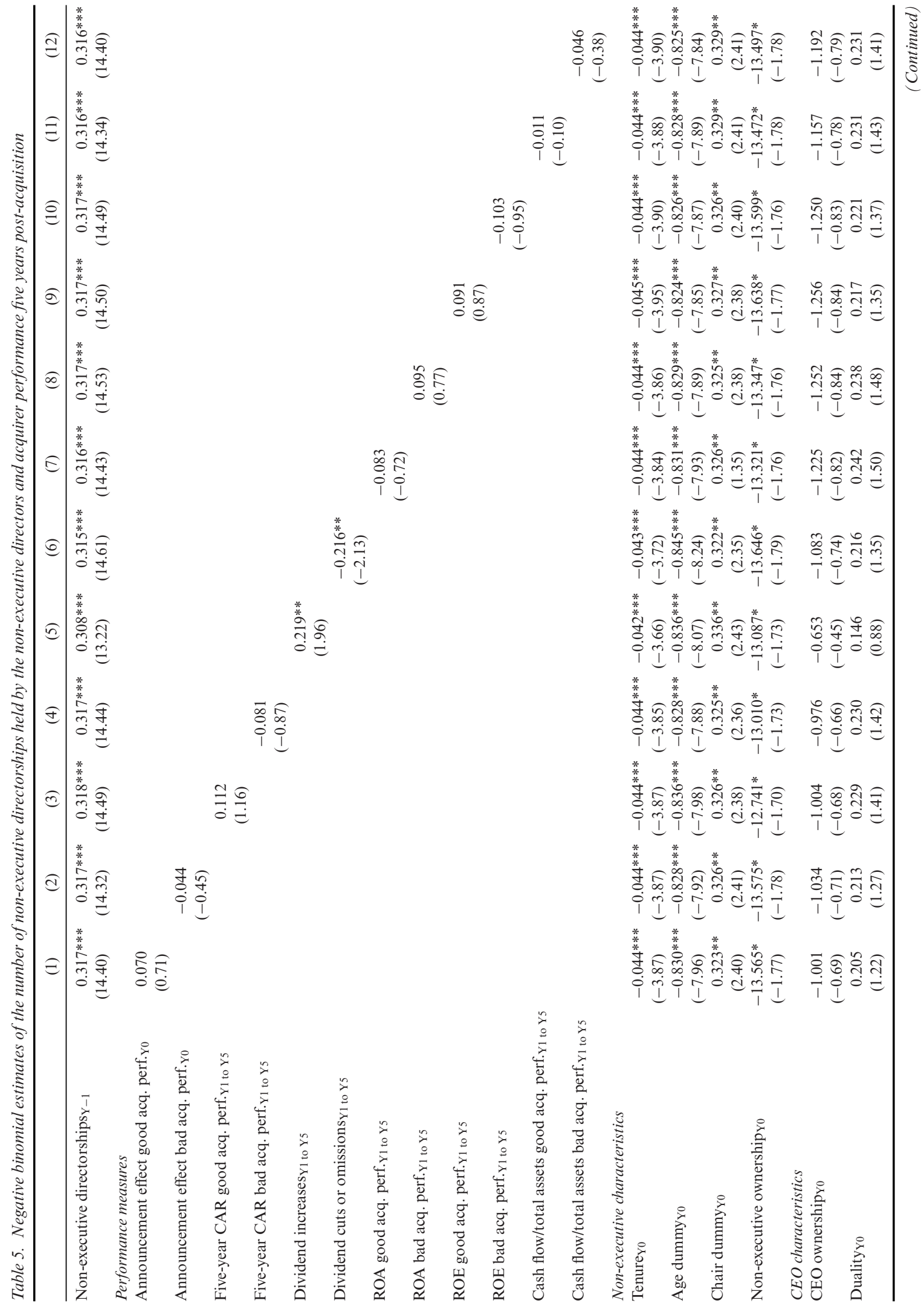




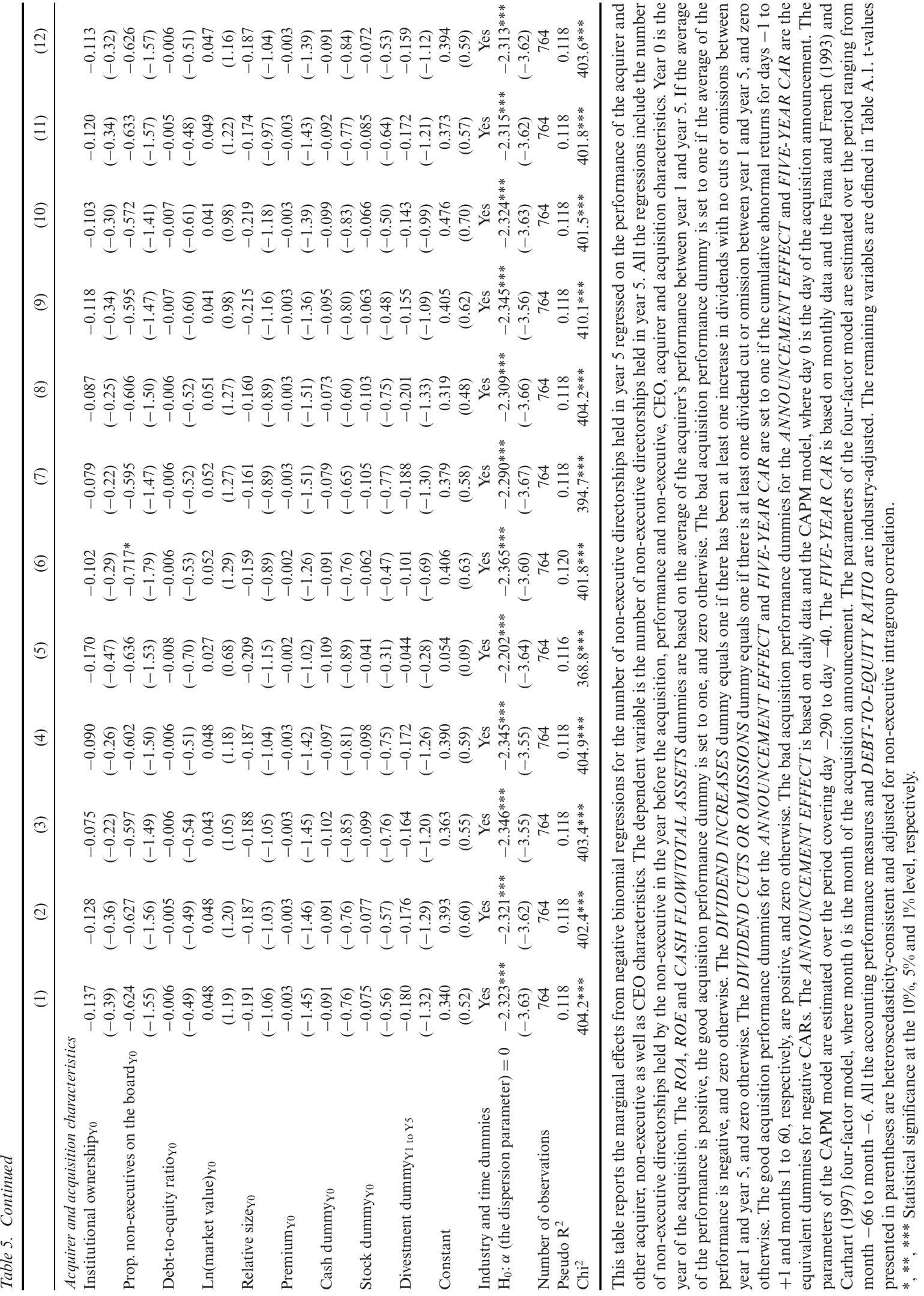


by dividend changes. ${ }^{18}$ Hence, our hypothesis is validated.

\section{Further and robustness tests}

\section{Further tests}

First, we explain why the number of directorships held by the non-executives is sensitive to dividend changes but not to market and accounting performance measures. Panel A of Table 6 reports the logit regressions using DIVIDEND INCREASES and DIVIDEND CUTS OR OMISSIONS, respectively, as the dependent variable regressed on $C A R[-1,1]$ and $C A R[1,60]$, the latter two in the form of continuous measures of performance. $C A R[-1,1]$ is insignificant in both regressions, whereas $C A R[1,60]$ is positive (negative) and significant at the $1 \%$ level $(5 \%$ level) when using DIVIDEND INCREASES (DIVIDEND CUTS OR OMISSIONS) as the dependent variable. This shows that acquirers experiencing a positive (negative) long-term market reaction are more likely to increase (cut or omit) dividends five years after the acquisition. Further, Panel B shows that the positive long-term market reaction to the announcement leads to higher EPS and DPS but not to higher ROA, ROE and CASH FLOWITOTAL AS$S E T S$ five years after the acquisition. Overall, this suggests that dividends are a more tangible and salient measure of performance post-acquisition, as acquirers pay out the extra value created by the acquisitions to their shareholders via increased dividends. Negative long-term market reactions result in lower or omitted dividends five years after the acquisition.

Second, to address endogeneity concerns, we rerun the regressions using the subsample of acquirers with a stable dividend policy prior to the acquisition. Following Goergen, Renneboog and Correia da Silva (2005), we define an acquirer as having a stable dividend policy if the acquirer reports positive dividends per share and earnings per share for the four years prior to the acquisition. Further analysis (not tabulated) shows that 141 of the 183 acquisitions in the sample are preceded by four years of stable dividend policy. We then rerun the regressions reported in Table 5 for

\footnotetext{
${ }^{18}$ Untabulated regressions show that our results are upheld after excluding the 44 of the 183 acquisitions which engaged in share repurchases in at least one year after the acquisition.
}

the subsample of acquirers with a stable dividend policy. The abridged negative binomial regressions reported in columns (1) and (2) of Table 7 confirm that our main results are upheld when using DIVIDEND INCREASES and DIVIDEND CUTS OR OMISSIONS. Untabulated regressions suggest that, similar to Table 5 , all the market and accounting-based performance measures are insignificant. Hence, our results are unlikely to be affected by endogeneity, such as unstable dividends pre-acquisition, which continue post-acquisition, and suggest that non-executives are indeed rewarded (penalized) for good (bad) acquisitions.

Finally, why does it make sense to use five years of post-acquisition performance? Are the nonexecutives rewarded (penalized) over shorter periods of time? The dependent variables in columns (3)/(4), (5)/(6) and (7)/(8) of Table 7 are the number of directorships held by the non-executive two, three and four years post-acquisition, respectively. The performance measures are also calculated for the respective period. For example, the dummy DIVIDEND INCREASES in column (3) equals one if there has been at least one increase in dividends with no cuts or omissions in years 1 and 2, and zero otherwise. The dummy DIVIDEND CUTS OR OMISSIONS used in column (4) of the same table equals one if there is at least one dividend cut or omission in years 1 and 2, and zero otherwise. For the two-year post-acquisition performance, the dividend change dummies are insignificant. However, we observe significant results when using the three-year and four-year post-acquisition dividend change dummies. This suggests that it takes up to three years for a non-executive to be rewarded (penalized) with additional (fewer) non-executive directorships. Bearing in mind that non-executives in the UK are typically up for (re-)election every three years, this result makes perfect sense. Also, in the context of an acquisition, a bad acquisition decision is unlikely to have an immediate, detrimental effect on performance, and the effect is more likely to be gradual.

To summarize, there is strong evidence that directors are punished for dividend cuts or omissions and rewarded for dividend increases, and this effect is upheld for acquirers with a stable dividend policy prior to the acquisition. This suggests that our results are driven by the non-executives' acquisition decisions rather than performance outcomes independent of acquisition decisions. 
Table 6. Is the market reaction at the announcement of the acquisition reflected in the dividend policy five years after the acquisition?

Panel A. Logit regressions explaining the likelihood of increasing versus cutting or omitting dividends

\begin{tabular}{|c|c|c|c|c|c|}
\hline & \multicolumn{2}{|l|}{$\begin{array}{l}\text { Dividend } \\
\text { increases } \\
\quad(1)\end{array}$} & $\begin{array}{l}\text { Dividend } \\
\text { cuts or } \\
\text { omissions } \\
\text { (2) }\end{array}$ & $\begin{array}{l}\text { Dividend } \\
\text { increases } \\
\text { (3) }\end{array}$ & $\begin{array}{l}\text { Dividend } \\
\text { cuts or } \\
\text { omissions } \\
\text { (4) }\end{array}$ \\
\hline $\mathrm{CAR}[-1,1]$ & \multicolumn{2}{|l|}{$\begin{array}{c}0.420 \\
(0.33)\end{array}$} & $\begin{array}{l}-0.365 \\
(-0.28)\end{array}$ & \multirow[b]{2}{*}{$\begin{array}{l}0.325^{* * *} \\
(2.68)\end{array}$} & \\
\hline $\mathrm{CAR}[1,60]$ & & & & $\begin{array}{l}-0.298^{* *} \\
(-2.44)\end{array}$ \\
\hline Constant & \multicolumn{2}{|l|}{$\begin{array}{l}-0.261^{*} \\
(-1.72)\end{array}$} & $\begin{array}{r}0.011 \\
(0.07)\end{array}$ & $\begin{array}{l}-0.188 \\
(-1.15)\end{array}$ & $\begin{array}{l}-0.063 \\
(-0.39)\end{array}$ \\
\hline Number of observations & \multicolumn{2}{|l|}{177} & 177 & 165 & 165 \\
\hline Pseudo $\mathrm{R}^{2}$ & \multicolumn{2}{|l|}{0.000} & 0.000 & 0.032 & 0.028 \\
\hline $\mathrm{Chi}^{2}$ & \multicolumn{2}{|l|}{0.111} & 0.078 & 7.196 & 5.955 \\
\hline \multicolumn{6}{|c|}{ Panel B. Comparing performance measures between acquirers with a positive and negative long-term market reaction } \\
\hline & \multicolumn{2}{|c|}{ Positive CAR[1,60] } & & Negative CAR[1,60] & \\
\hline & $\begin{array}{l}\text { Mean } \\
(1)\end{array}$ & $\begin{array}{l}\text { Median } \\
\text { (2) }\end{array}$ & $\begin{array}{l}\text { Mean } \\
\text { (3) }\end{array}$ & $\begin{array}{l}\text { Median } \\
\text { (4) }\end{array}$ & $\begin{array}{l}\mathrm{t} \text {-test/z-test } \\
\text { (5) }\end{array}$ \\
\hline $\mathrm{EPS}_{\mathrm{Y} 5}$ & 38.359 & 28.710 & 27.384 & 17.800 & $1.50 / 3.14^{* * *}$ \\
\hline $\mathrm{DPS}_{\mathrm{Y} 5}$ & 15.245 & 11.500 & 10.385 & 6.450 & $1.62 / 2.51^{* *}$ \\
\hline $\mathrm{ROA}_{Y 5}$ & 0.108 & 0.114 & 0.098 & 0.094 & $0.52 / 0.38$ \\
\hline $\mathrm{ROE}_{Y 5}$ & 0.116 & 0.116 & 0.183 & 0.115 & $-0.25 / 0.57$ \\
\hline Cash flow/total assetsy5 & 0.067 & 0.077 & 0.072 & 0.067 & $-0.17 / 0.06$ \\
\hline Industry-adjusted $\mathrm{ROA}_{\mathrm{Y} 5}$ & 0.157 & 0.048 & 0.163 & 0.055 & $-0.06 /-0.18$ \\
\hline Industry-adjusted $\mathrm{ROE}_{Y 5}$ & 0.257 & 0.047 & 0.458 & 0.059 & $-0.42 /-0.11$ \\
\hline $\begin{array}{l}\text { Industry-adjusted cash } \\
\text { Flow/total assetsy5 }\end{array}$ & 0.382 & 0.033 & 0.142 & 0.050 & $0.78 /-0.07$ \\
\hline $\begin{array}{l}\text { Average industry-adjusted } \\
\text { ROA }_{Y 1 \text { to } Y 5}\end{array}$ & 0.115 & 0.035 & 0.114 & 0.039 & $0.01 /-0.50$ \\
\hline $\begin{array}{l}\text { Average industry-adjusted } \\
\text { ROE }_{Y 1 \text { to } Y 5}\end{array}$ & 0.028 & 0.022 & 0.181 & 0.055 & $0.76 / 0.16$ \\
\hline $\begin{array}{l}\text { Average industry-adjusted } \\
\text { Cash flow/total } \\
\text { assets } 1 \text { to Y5 }\end{array}$ & -0.042 & 0.023 & 0.017 & 0.031 & $-0.36 /-0.25$ \\
\hline
\end{tabular}

Panel A reports the logit estimates of the likelihood of the acquirer increasing (cutting or omitting dividends) five years after the acquisition for the 183 acquisitions. The dependent variable in columns (1) and (3) is the DIVIDEND INCREASES dummy, which equals one if there has been at least one increase in dividends with no cuts or omissions between year 1 and year 5 , and zero otherwise. The dependent variable in columns (2) and (4) is the DIVIDEND CUTS OR OMISSIONS dummy, which equals one if there is at least one dividend cut or omission between year 1 and year 5, and zero otherwise. The independent variables are the short-term (i.e. $C A R[-1,1]$ ) and long-term (i.e. $C A R[1,60]$ ) market reaction to the announcement of the acquisitions, both measured as continuous performance measures. $C A R[-1,1]$ is based on daily data and the CAPM model, where day 0 is the day of the acquisition announcement. The parameters of the CAPM model are estimated over the period covering day -290 to day -40 . CAR $[1,60]$ is based on monthly data and the Fama and French (1993) and Carhart (1997) four-factor model, where month 0 is the month of the acquisition announcement. The parameters of the four-factor model are estimated over the period ranging from month -66 to month -6 . Panel B compares the means and medians of performance measures between acquirers with positive and negative long-term market reactions. EPS (earnings per share), DPS (dividends per share), ROA (return on assets), ROE (return on equity) and CASH FLOWITOTAL ASSETS are measured in year 5, unless otherwise specified. The remaining variables are defined in Table A.1. Differences in means are assessed using a t-test, whereas differences in medians are tested using a z-test (Wilcoxon rank-sum).

$*, * *, * * *$ Statistical significance at the $10 \%, 5 \%$ and $1 \%$ level, respectively.

\section{Quality rather than quantity of non-executive directorships held}

It may be that non-executives are not rewarded in the form of an increase in the quantity of non-executive directorships, but rather in the form of better-quality directorships. Better-quality directorships may manifest themselves in three different ways. First, non-executive directorships in 


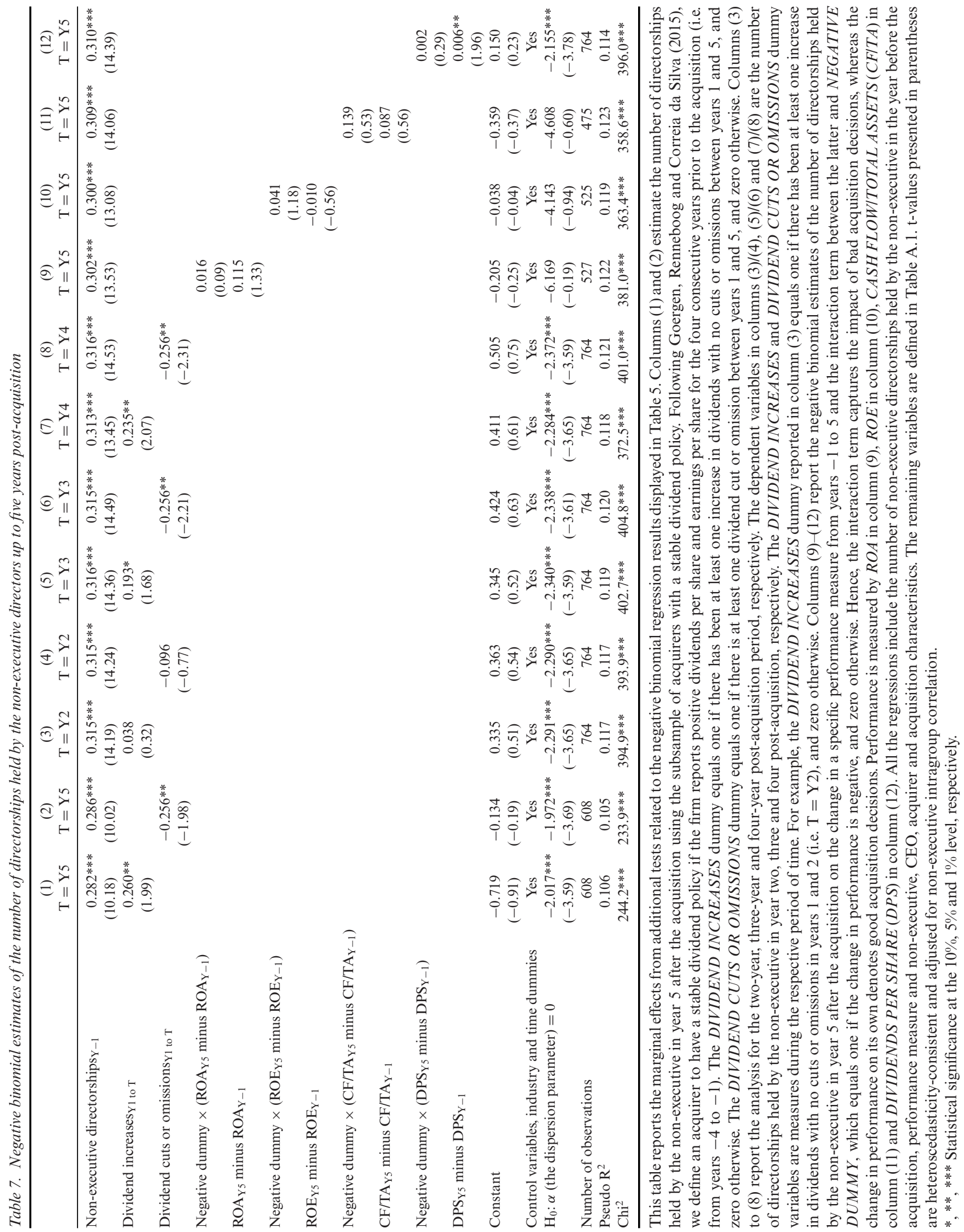


FTSE 100 firms may be more prestigious than nonexecutive directorships in smaller firms. Second, a similar case can be made for non-executive directorships in firms that are part of the Official List compared with those on the AIM. Finally, nonexecutives may be rewarded with chair positions rather than regular non-executive directorships.

Using the 296 non-executives who are still in the labour market in year 5, and are involved with only one acquisition during the period of study, we run ordinary least squares (OLS) regressions where the change in the proportion of directorships in FTSE 100 , AIM and chair positions from years 0 to 5 is the dependent variable. The regression results (not tabulated) show that post-acquisition performance has no consistent impact on the change in the proportion of higher-quality board seats held by the non-executives. Hence, our results are upheld.

\section{Compensation of directors and acquirers' post-acquisition performance}

Next we use the cash compensation of nonexecutives as an alternative reward mechanism. ${ }^{19}$ The average cash compensation of individual nonexecutives measured in year 0 is used as an explanatory variable and their respective average individual cash compensation in year 5 is used as an alternative dependent variable to the number of directorships. ${ }^{20}$ However, this regression specification suffers from selection bias, since a director who is no longer in the labour market in year 5 will have zero compensation in that year. To address this issue, we use a Heckman selection procedure where the first-step equation is a logit regression

\footnotetext{
${ }^{19}$ Director compensation is obtained from BoardEx, which provides comprehensive compensation data starting with 1999. Hence, we focus on the 116 of the 183 acquisitions in the sample completed between January 1999 and December 2010 and the 426 non-executives involved in these acquisitions. As some directors participate in more than one acquisition, the total number of observations in the remuneration sample is 525. Cash compensation is defined as the base salary plus bonus. Only 11 of the 426 non-executives (not tabulated) with available remuneration data receive equity-based compensation in year 0 and also year 5 . As equity-based compensation for non-executives has been consistently discouraged by the UK corporate governance codes, this low number is not surprising. The analysis in this section is based on the cash compensation only.

${ }^{20}$ Average cash compensation is used instead of cash compensation to control for the number of directorships held by the director.
}

explaining the likelihood of the director participating in the labour market until year 5. The secondstep OLS regressions use the natural logarithm of one plus the average cash compensation of individual non-executives in year 5 as the dependent variable and the Mill's ratio, performance, nonexecutive characteristics, CEO, acquirer and acquisition characteristics as independent variables. All the regressions also include the natural logarithm of one plus the average cash compensation of the non-executive in year 0 on the right-hand side. We find that the acquirer's performance postacquisition does not have an impact on the average cash compensation of the non-executives in year 5 (not tabulated). Similar results are obtained when we use total compensation, which is the sum of the cash and equity-based compensation.

\section{Alternative performance measures}

The following four alternative types of performance measures are used. First, we use the average for years 1 to 5 for the accounting measures of performance and the actual (continuous) values for the market-based measures of performance instead of the acquisition performance dummies. Second, following Martin and Shalev (2017), the differences in the post- and pre-acquisition performance of the acquirer are used instead of the acquisition dummies. For example, for $R O A$, this difference is calculated as $R O A$ in year 5 minus $R O A$ in year -1 . Given that we are interested in segregating the impact of good and bad acquisition decisions, we interact the change in the continuous performance measures of the acquirer (i.e. ROA 5 minus $\mathrm{ROA}_{\mathrm{Y}-1}$ ) with NEGATIVE DUMMY, which equals one if the change in ROA is negative, and zero otherwise. Hence, the interaction term between the change in performance and NEGATIVE $D U M M Y$ captures the impact of bad acquisition decisions only. We then include the change in the performance measures and their respective interaction terms with NEGATIVE DUMMY in the negative binomial regressions reported in Table 5. These results are tabulated in columns (9) to (12) of Table 7. Third, we measure performance using good and bad dividend payout dummy variables, which are set to one if the average industryadjusted dividend payout ratio for years 1 to 5 is positive and negative, respectively, and zero otherwise. The industry adjustment is done for each annual observation by subtracting the industry 
mean dividend payout ratio based on the threedigit SIC codes. Finally, we base ANNOUNCE$M E N T$ EFFECT on various alternative windows (i.e. $[-1,0],[0,+1],[-2,+2],[0,+20]$ and $[-20,+20])$, where again day 0 is the day of the acquisition announcement. Our results are robust to the above alternative types of performance measures. Performance is significant only when it is based on dividends.

\section{Alternative estimation techniques and subsample analysis}

Our results are also robust when using the following three alternative estimation techniques. First, we categorize the changes in the number of non-executive directorships from years 0 to 5 for each non-executive into decreases, no changes and increases. We run an ordered logit regression using this ordinal variable as the dependent variable and the number of directorships in year -1 , the acquisition performance dummies, non-executive, CEO, acquirer and acquisition characteristics as the independent variables. Second, we use logit regressions to estimate the likelihood that a non-executive no longer holds non-executive directorships in year 5 . Third, we rerun our main model using OLS and the change in the number of directorships (i.e. directorships held in year $5 \mathrm{mi}$ nus directorships held in year 0 ) as the dependent variable. Our results are upheld.

Further, given that performance is measured over a five-year period, to avoid any contamination effects, we rerun the analysis using the subsample of acquirers that participated in one acquisition only during the period of the study. We have also identified that 14 of the 156 acquirers in the sample do not pay any dividends from years -5 to -1 . We rerun our analysis on the subsample of observations after excluding the 54 out of 771 observations in the sample associated with these 14 acquirers. Our results are upheld.

\section{Corporate governance reforms}

Corporate governance reforms, specifically the Higgs (2003) recommendation that $50 \%$ of the board should be comprised of non-executives, may have exogenously increased the number of nonexecutive directorships held by the non-executives. Hence, we rerun the regressions in Table 5 separately for the pre- and post-2003 periods. Our results remain when we control for the potential impact of the Higgs recommendations.

\section{Conclusion and discussion}

Over the past two decades, the quality of board governance has become a key component of the UK corporate governance architecture. In particular, as a result of successive corporate governance codes, there has emerged a sharper distinction between the monitoring role of non-executives and the management role of executives. Central to these developments is a desire to ensure that non-executives are able to monitor management behaviour and corporate decisions are made in the interests of shareholders. Underlying this revised emphasis on the role of boards is a belief that a market exists for the services of non-executives and, as a result, better-quality non-executives are expected to be rewarded with further nonexecutive appointments as other firms seek to capture their expertise for their own boards. Similarly, those non-executives perceived as being inadequate advocates of shareholder welfare are expected to encounter a reduced demand for their services from other firms.

This study examines the efficiency of the labour market for non-executives by investigating whether the post-acquisition performance of acquirers influences the number of non-executive directorships that non-executives involved in these acquisition decisions hold up to five years after the acquisition. Our analysis consistently reveals that the subsequent holding of non-executive directorships by non-executives is sensitive to post-acquisition performance when measured by dividend changes but not market and accounting performance measures. These findings contribute to our knowledge of the non-executive labour market for several reasons. First, our findings suggest that the UK labour market for non-executives is efficient and rewards as well as punishes non-executives for the quality of their acquisition decisions. Second, the link between dividends and the subsequent holding of non-executive directorships identifies the key role dividends have in investors' perceptions of non-executive performance. We show that dividends are a more tangible and salient measure of performance compared with market and accounting performance measures, because acquirers pay out the extra value created by the 
acquisitions to their shareholders via increased dividends. Bad acquisition decisions, which are associated with negative long-term market reactions, end in lower or omitted dividends five years after the acquisition. Finally, we show that a bad acquisition decision is unlikely to have an immediate, detrimental effect on performance as its effect on a non-executive's career is gradual. To the best of our knowledge, this is the first study that investigates the impact of the quality of a decision taken by a non-executive director on his/her future career in the context of acquisitions using dividend changes as a measure of post-acquisition performance. Our study complements that of Kaplan and Reishus (1990), who find that the careers of top executives are negatively affected by dividend cuts in general (i.e. not in the context of acquisitions). We show that, in the case of the non-executives on the board of the acquirers, investors view dividend changes as the result of good (or bad) acquisition decisions.

Why do we find that dividends affect the future careers of the non-executive directors whereas other performance measures do not have an effect? First, dividends are more tangible for most investors. They are cash in hand and certain investors (e.g. pension funds) may rely on dividends to meet their own liabilities. This is consistent with Bhattacharya's (1979: 260) '[t]he old "bird in the hand" arguments that agents have to realise their wealth for consumption and that, somehow, dividends are "superior" to capital gains for this purpose $[\ldots]$ '. Second, dividends are a more salient measure of performance than market and accounting measures of performance. More specifically, Lintner (1956) found that managers are reluctant to change dividends, unless the change is warranted by a permanent change in earnings. Finally, as highlighted by Easterbrook (1984), La Porta et al. (2000) and Sharma (2011), amongst others, shareholders value regular dividends not only because they are a mechanism for returning corporate earnings to investors, but also because by paying regular dividends companies are forced to return to the capital markets if they require funds. This, in turn, allows investors to have some oversight of directors regarding the management of the company and the quality of non-executive monitoring of that management. Indeed, Sharma (2011) finds that non-executive tenure is sensitive to the continuation of dividends being paid and attributes this to recognition by non-executives of the value to shareholders of maintaining dividend payments. Therefore, we believe that dividend changes must be taken into account when exploring the impact of post-acquisition performance on the future careers of non-executive directors.

\section{Appendix}

Table A.1. Definitions of variables

\begin{tabular}{|c|c|}
\hline Variable & Definition \\
\hline Number of directorships & $\begin{array}{l}\text { Number of non-executive directorships held by an individual non-executive five years after the } \\
\text { acquisition. }\end{array}$ \\
\hline $\begin{array}{l}\text { Non-executive directorships } \\
\text { held before the } \\
\text { acquisition }\end{array}$ & Number of non-executive directorships held by the non-executive in year -1 . \\
\hline \multicolumn{2}{|l|}{ Performance measures } \\
\hline Announcement effect & $\begin{array}{l}\text { This market-based measure of acquirer performance is based on daily data and the capital asset pricing } \\
\text { model (CAPM). It is defined as the cumulative abnormal returns for days }-1 \text { to }+1 \text {, where day } 0 \text { is } \\
\text { the day of the acquisition announcement. The parameters of the CAPM are estimated over the } \\
\text { period covering days }-290 \text { to }-40 \text {. The good (bad) acquisition performance dummy for } \\
\text { ANNOUNCEMENT EFFECT is set to one if the latter is positive (negative), and zero otherwise. }\end{array}$ \\
\hline Five-year CAR & $\begin{array}{l}\text { This market-based measure of acquirer performance is based on monthly data and the Fama and } \\
\text { French (1993) and Carhart (1997) four-factor model. It is calculated as the cumulative abnormal } \\
\text { returns from months } 1 \text { to } 60 \text {, where month } 0 \text { is the month of the acquisition announcement. The } \\
\text { parameters of the four-factor model are estimated over the period ranging from months }-66 \text { to }-6 \text {. } \\
\text { The good (bad) acquisition dummy for FIVE-YEAR CAR is equal to one if the latter is positive } \\
\text { (negative), and zero otherwise. }\end{array}$ \\
\hline
\end{tabular}


Table A.1. Continued

\begin{tabular}{|c|c|}
\hline Variable & Definition \\
\hline Dividend changes & $\begin{array}{l}\text { This is a dividend-based measure of acquirer performance. DIVIDEND INCREASES is a dummy } \\
\text { variable that is set to one if there has been at least one increase in the acquirer's dividends with no } \\
\text { cuts or omissions between years } 1 \text { and 5, and zero otherwise. The dummy DIVIDEND CUTS OR } \\
\text { OMISSIONS equals one if there is at least one dividend cut or omission between years } 1 \text { and 5, and } \\
\text { zero otherwise. }\end{array}$ \\
\hline ROA & $\begin{array}{l}\text { This accounting-based measure of acquirer performance is calculated as earnings before interest, taxes } \\
\text { and depreciation divided by total assets and it is industry-adjusted by subtracting from each annual } \\
\text { observation the mean industry performance using the three-digit SIC codes from Datastream. We } \\
\text { transform the latter into good and bad acquisition performance dummies. These dummies are set to } \\
\text { one if the average of the acquirer performance is positive and negative, respectively, between years } 1 \\
\text { and 5, and set to zero otherwise. }\end{array}$ \\
\hline ROE & $\begin{array}{l}\text { This accounting-based measure of acquirer performance is calculated as earnings after interest and tax } \\
\text { divided by common equity and it is industry-adjusted by subtracting from each annual observation } \\
\text { the mean industry performance using the three-digit SIC codes from Datastream. We transform the } \\
\text { latter into good and bad acquisition performance dummies. These dummies are set to one if the } \\
\text { average of the acquirer's performance is positive and negative, respectively, between years } 1 \text { and } 5 \text {, } \\
\text { and set to zero otherwise. }\end{array}$ \\
\hline Cash flow/total assets & $\begin{array}{l}\text { This accounting-based measure of acquirer performance is calculated as the pre-depreciation profit } \\
\text { divided by total assets and it is industry-adjusted by subtracting from each annual observation the } \\
\text { mean industry performance using the three-digit SIC codes from Datastream. We transform the } \\
\text { latter into good and bad acquisition performance dummies. These dummies are set to one if the } \\
\text { average of the acquirer's performance is positive and negative, respectively, between years } 1 \text { and } 5 \text {, } \\
\text { and set to zero otherwise. }\end{array}$ \\
\hline DPS & Dividends per share in the respective year. \\
\hline EPS & Earnings per share in the respectiv \\
\hline \multicolumn{2}{|l|}{ Non-executive characteristics } \\
\hline Tenure & $\begin{array}{l}\text { The number of years the non-executive has served on the board of the acquirer at the completion of the } \\
\text { acquisition. }\end{array}$ \\
\hline Age dummy & $\begin{array}{l}\text { This is a dummy variable that equals one if the age of the non-executive at the completion date of the } \\
\text { acquisition is } 60 \text { or more, and zero otherwise. }\end{array}$ \\
\hline Chair dummy & $\begin{array}{l}\text { This is a dummy variable that takes a value of one if the non-executive is the chair of the board in year } \\
0 \text {, and zero otherwise. }\end{array}$ \\
\hline $\begin{array}{l}\text { Non-executive ownership } \\
\text { CEO characteristics }\end{array}$ & The proportion of the acquirer's equity held by the non-executive in year 0 . \\
\hline CEO ownership & The proportion of the acquirer's equ \\
\hline Duality & $\begin{array}{l}\text { This is a dummy variable that takes a value of one if the CEO is the chair of the acquirer's board in year } \\
0 \text {, and zero otherwise. }\end{array}$ \\
\hline \multicolumn{2}{|c|}{ Acquirer and acquisition characteristics } \\
\hline Institutional ownership & $\begin{array}{l}\text { The proportion of the acquirer's equity held by UK institutional investors in excess of } 3 \% \text { in year } 0 \text {. } \\
\text { The latter include banks, insurance companies, pension funds, unit trusts, investment trusts, } \\
\text { investment offices and firms providing investment advice. }\end{array}$ \\
\hline $\begin{array}{l}\text { Proportion of } \\
\text { non-executives on board }\end{array}$ & $\begin{array}{l}\text { The number of non-executives on the board of the acquirer divided by the total number of directors on } \\
\text { the board in year } 0 \text {. }\end{array}$ \\
\hline Debt-to-equity ratio & $\begin{array}{l}\text { Total debt measured as a percentage of common equity of the acquirer in year } 0 \text {, industry-adjusted by } \\
\text { subtracting from each annual observation the mean industry debt-to-equity ratio calculated using } \\
\text { the three-digit SIC codes. It is winsorized at the } 1 \text { st and } 99 \text { th percentiles. }\end{array}$ \\
\hline $\operatorname{Ln}($ market value) & $\begin{array}{l}\text { Natural logarithm of the year-end share price multiplied by the number of total shares outstanding in } \\
\text { year } 0 \text {. }\end{array}$ \\
\hline Relative size & $\begin{array}{l}\text { The market value of the target expressed as the proportion of the market value of the acquirer } 40 \text { days } \\
\text { prior to the acquisition announcement date. }\end{array}$ \\
\hline Premium & $\begin{array}{l}\text { The difference between the offer price and the target share price one day before the effective date of the } \\
\text { acquisition divided by the target share price one day before the acquisition. }\end{array}$ \\
\hline Cash dummy & A dummy variable that equals one if the acquisition is financed by cash only, and zero otherwise. \\
\hline Stock dummy & A dummy variable which is set to one if stock only is used to pay for the acquisition, and zero otherwise. \\
\hline Divestment dummy & $\begin{array}{l}\text { A dummy variable which equals one if there is at least one reduction of } 25 \% \text { or greater in total assets of } \\
\text { the acquirer from years } 1 \text { to } 5 \text {, and zero otherwise. This dummy variable accounts for the fact that } \\
\text { bad deals are often divested. }\end{array}$ \\
\hline Industry dummies & Based on the Fama and French 10 industry portfolio classification (see http://ow.ly/ypra309kuVZ). \\
\hline
\end{tabular}




\section{References}

Adams, R. B., B. E. Hermalin and M. S. Weisbach (2010). 'The role of boards of directors in corporate governance', Journal of Economic Literature, 48, pp. 58-107.

Agrawal, A. and J. F. Jaffe (2000). 'The post-merger performance puzzle', Advances in Mergers and Acquisitions, 1, pp. 7-41.

Armour, J. and D. A. Skeel (2007). 'Who writes the rules for hostile takeovers and why? The peculiar divergence of US and UK takeover regulation', The Georgetown Law Journal, 95, pp. 1727-1794.

Bhagat, S. and B. Black (2002). 'The non-correlation between board independence and long-term firm performance', Journal of Corporation Law, 27, pp. 232-273.

Bhattacharya, S. (1979). 'Imperfect information, dividend policy and "the bird in the hand" fallacy', Bell Journal of Economics, 10, pp. 259-270.

Brickley, J., J. Linck and J. Coles (1999). 'What happens to CEOs after they retire? New evidence on career concerns, horizon problems, and CEO incentives', Journal of Financial Economics, 52, pp. 341-377.

Brochet, F. and S. Srinivasan (2014). 'Accountability of independent directors: evidence from firms subject to securities litigation', Journal of Financial Economics, 111, pp. 430449.

Cadbury, A. (1992). Report of the Committee on the Financial Aspects of Corporate Governance. London: GEE.

Carhart, M. (1997). 'On persistence in mutual fund performance', Journal of Finance, 52, pp. 57-82.

Chhaochharia, V. and Y. Grindstein (2007). 'The changing structure of US corporate boards: 1997-2003', Corporate Governance: An International Review, 15, pp. 1215-1223.

Combined Codes (1999, 2003, 2006, 2008). The Combined Code on Corporate Governance. London: Financial Reporting Council.

Dahya, J., J. J. McConnell and N. G. Travlos (2002). 'The Cadbury Committee, corporate performance, and top management turnover', Journal of Finance, 57, pp. 461-483.

Dalton, C. M. and D. R. Dalton (2005). 'Boards of directors: utilizing empirical evidence in developing practical prescriptions', British Journal of Management, 16, pp. S91-S97.

Davidoff, S. M., A. C. W. Lund and R. Schonlau (2014). 'Do outside directors face labor market consequences? A natural experiment from the financial crisis', Harvard Business Law Review, 4, pp. 53-83.

Duru, A., D. Wang and Y. Zhao (2013). 'Staggered boards, corporate opacity and firm value', Journal of Banking and Finance, 37, pp. 341-360.

Easterbrook, F. (1984). 'Two agency cost explanations of dividends', American Economic Review, 74, pp. 650-659.

Espenlaub, S., A. Khurshed and A. Mohamed (2012). 'IPO survival in a reputational market', Journal of Business Finance \& Accounting, 39, pp. 427-463.

Fairchild, L. and J. Li (2005). 'Director quality and firm performance', Financial Review, 40, pp. 257-279.

Fama, E. F. (1980). 'Agency problems and the theory of the firm', Journal of Political Economy, 88, pp. 288-307.

Fama, E. F. and K. R. French (1993). 'Common risk factors in the returns on stocks and bonds', Journal of Financial Economics, 33, pp. 3-56.
Fama, E. F. and M. C. Jensen (1983). 'Separation of ownership and control', Journal of Law and Economics, 26, pp. 301325.

Farrell, K. A. and D. A. Whidbee (2000). 'The consequences of forced CEO succession for outside directors', Journal of Business, 73, pp. 597-627.

Ferris, S. P., M. Jagannathan and A. C. Pritchard (2003). 'Too busy to mind the business? Monitoring by directors with multiple board appointments', Journal of Finance, 58, pp. 10871111.

Fich, E. M. and A. Shivdasani (2007). 'Financial fraud, director reputation and shareholder wealth', Journal of Financial Economics, 86, pp. 306-336.

Fos, V. and M. Tsoutsoura (2014). 'Shareholder democracy in play: career consequences of proxy contests', Journal of Financial Economics, 114, pp. 316-340.

Goergen, M., L. Renneboog and L. Correia da Silva (2005). 'When do German firms change their dividends?', Journal of Corporate Finance, 11, pp. 375-399.

Harford, J. (2003). 'Takeover bids and target directors' incentives: the impact of a bid on directors' wealth and board seats', Journal of Financial Economics, 69, pp. 51-83.

Harford, J. and R. J. Schonlau (2013). 'Does the director labor market offer ex post settling-up for CEOs? The case of acquisitions', Journal of Financial Economics, 110, pp. 18-36.

Harford, J., M. Humphery-Jenner and R. Powell (2012). 'The sources of value destruction in acquisitions by entrenched managers', Journal of Financial Economics, 106, pp. 247-261.

Hermalin, B. E. and M. S. Weisbach (2003). 'Boards of directors as an endogenously determined institution: a survey of the economic literature', Economic Policy Review, 9, pp. 7-26.

Higgs (2003). Review of the Role and Effectiveness of Non-Executive Directors. Available at: http://ecgi.global/code/ higgs-report-review-role-and-effectiveness-non-executivedirectors

Jiraporn, P., P. Chintrakarn and Y. S. Kim (2012). 'Analyst following, staggered boards, and managerial entrenchment', Journal of Banking and Finance, 36, pp. 3091-3100.

Kaplan, S. and D. Reishus (1990). 'Outside directorships and corporate performance', Journal of Financial Economics, 27, pp. 389-410.

La Porta, R. F. Lopez-De-Silanes, A. Shleifer and R. W. Vishny (2000). 'Agency problems and dividend policies around the world', Journal of Finance, 55, pp. 1-33.

Lintner, J. (1956). 'Distribution of incomes of corporations among dividends, retained earnings, and taxes', American Economic Review, 46, pp. 97-113.

Martin, X. and R. Shalev (2017). 'Target firm-specific information and acquisition efficiency', Management Science, 63, pp. 672-690.

Martynova, M. and L. D. R. Renneboog (2006). 'Mergers and acquisitions in Europe'. In L. D. R. Renneboog (ed.), Advances in Corporate Finance and Asset Pricing, pp. 13-75. Amsterdam: Elsevier.

Masulis, R. W., C. Wang and F. Xie (2007). 'Corporate governance and acquirer returns', Journal of Finance, 62, pp. 18511889.

Rose, M. J. (2009). 'Heterogeneous impacts of staggered boards by ownership concentration', Journal of Corporate Finance, 19 , pp. 113-128. 
Rozeff, M. S. (1982). 'Growth, beta and agency costs as determinants of dividend payout ratios', Journal of Financial Research, 5, pp. 249-259.

Sharma, V. (2011). 'Independent directors and the propensity to pay dividends', Journal of Corporate Finance, 17, pp. 10011015.

Tuch, C. and N. O'Sullivan (2007). 'The impact of acquisitions on firm performance: a review of the evidence',
International Journal of Management Reviews, 9, pp. 141170.

UK Corporate Governance Codes (2010, 2012, 2014, 2016). UK Corporate Governance Codes. London: Financial Reporting Council.

Yermack, D. (2004). 'Remuneration, retention and reputation incentives for outside directors', Journal of Finance, 59, pp. 22812308 .

Svetlana Mira is a Lecturer in Finance at Cardiff Business School, Cardiff University. Her main area of research is corporate finance. She conducts research on corporate governance, family firms, financial analysts and risk management. Svetlana has published her work in journals such as the Journal of Corporate Finance, European Financial Management and the Journal of Forecasting.

Marc Goergen holds a Chair in Finance at Cardiff Business School, Cardiff University. Previous appointments include the Universities of Manchester, Reading and Sheffield, as well as UMIST. He is also a Research Member of the prestigious European Corporate Governance Institute. Marc has published extensively on corporate governance, corporate finance and comparative capitalism. His research has appeared in the Journal of Finance, Journal of Corporate Finance, Journal of Financial Intermediation and Journal of Law, Economics and Organization. Marc has also written a successful textbook on corporate governance, which has been translated into Greek and Mandarin.

Noel O'Sullivan is Professor of Accounting at the School of Business and Economics, Loughborough University. His main research interest is corporate governance, specifically non-executive directors, multiple directorships, mergers and acquisitions, and various aspects of auditing. His research has been published in management and accounting journals including the British Journal of Management, Human Resource Management Journal, International Journal of Management Reviews, the British Accounting Review, Accounting and Business Research and the European Economic Review. 